\title{
Audience and Social Criticism in Sisir Tanah Songs
}

\author{
Anang Masduki ${ }^{\mathrm{a}, 1, *}$, Panqiang Niu ${ }^{\mathrm{b}, 2}$, Rr. Octa Dwina Fauzia ${ }^{\mathrm{c}, 3}$ \\ ${ }^{a}$ Assistant Professor in Communication Studies at Universitas Ahmad Dahlan, Yogyakarta, 55166, Indonesia, and a Ph.D. student at the School of \\ Journalism and Communication, Shanghai University of China. \\ ${ }^{\mathrm{b}}$ Associate Professor at the School of Journalism and Communication, Shanghai University of China. \\ c, Undergraduate Universitas Ahmad Dahlan Yogyakarta, 55166, Indonesia. \\ ${ }^{1}$ anang.masduki@fsbk.uad.ac.id*; ${ }^{2}$ panqiangniu@163.com; ${ }^{3}$ dhetaocta@gmail.com \\ * corresponding author
}

\section{ARTICLE INFO}

Article history

Received 2020-08-23

Revised 2020-09-01

Accepted 2020-09-05

Keywords

Audience

Sisir Tanah

Social Criticism

Mass Communication

Musical Communication

\section{ABSTRACT}

This research focuses on social criticism in an environment that is reflected in the lyrics of Sisir Tanah songs. The songs of Sisir Tanah are entirely focused on highlighting social issues, especially the environment in today's society. The purpose of this study is to describe audience reception as a resource person on how to see the role of Sisir Tanah songs as media to convey messages of social criticism. This research uses a descriptive qualitative method with a reception analysis method. The primary data is taken from the two songs of Sisir Tanah, namely Hidup and Bebal. The following data is obtained from interviews from several sources, journals, books, and the internet. The researcher also uses an interdisciplinary approach as a method of communication science studies whose lyrics are delivered by Sisir Tanah in the music media, social criticism theory, which describes Sisir Tanah into the category of social criticism in the environment, and the theory of respect analysis, which is the basis of the interview result of several speakers in interpreting the songs of Sisir Tanah. The results of this study show that social criticism through music media, in this case, is a song, is quite useful. Because the five speakers: Labib, Riska, Dedy, Sonnia, and Fachri, feel the social critique message delivered by Sisir Tanah through music becomes active when the listeners of the music can receive the message conveyed, as well as the effects obtained by the five speakers.

This is an open-access article under the CC-BY-SA license.

\section{Introduction}

Music is a series of tones or notations summarized into strains, packed with lyrics that are in harmony and put together. Such is music in general. Not only that, but music can also be a medium from the musician to the listeners. Usually, the messages are a meaning of feeling expressed into a song. Music also has a significant influence on the public. The function of music includes emotional expression, aesthetic appreciation, communication, symbolism, physical reaction, relating to social norms, ratification of social institutions, cultural continuity, community integration, and entertainment [1]. Music can be a medium for delivering messages or self-appreciation for the existing reality or become a satire/insinuation to specific individuals or groups. Music can also be an abusive media message, where the message conveyed is criticism [2]. Criticism is a response that is usually in the form of evaluation accompanied by a description and excellent and lousy consideration. Most musicians give social criticism against something global or social community [3]. Social criticism can be conveyed through the lyrics poured into a song where the lyrics contain criticism; it can be anything such as about the government or satire to individuals to individuals.

The issue of music as criticism has indeed been studied by many. However, the issue of Audience and Social Criticism in the song Sisir Tanah is almost non-existent so that this research will reveal the 
problem. McClary's research addresses criticism of music from a feminist perspective. According to McClary, the discipline of musicology is relatively untouched by feminism, so that McClary tries to rediscover the contribution of women in the history of music. According to McClary, traditional music is not only against feminist criticism but all forms of criticism that are socially based. McClary argues that music is resistant to interpretations that can build patterns of shaping the social world, such as gender, sexuality, race, ethnicity, and class [4]. Weitzman's study is very relevant to see to what extent music as criticism is developed. Weitzman reviews Adorno's views on music. Why? Because Adorno's work is involved in a severe battle with many aspects of the musicological research. Adorno's social critique was incisive and was implicit in all of his musical criticisms. Adorno examines the process in bourgeois society in which elements of deprivation are sure to be found and in which situations the role of cultural criticism is indispensable. According to Weitzman, social criticism has the most significant impact as long as a person has knowledge and experience of cultural patterns [5].

Looking at the results of Weitzman's research, I think that social criticism in the song Sisir Tanah is a cultural response expressed in the form of cultural criticism, and music plays a vital role in the delivery of social criticism. Klein, in his article, discusses the impact of cultural differences on the formation of critical authority through the examination of famous music critics. Klein attempted to describe the experiences of critics of popular culture. Klein argues that, in music criticism, musical, cultural objects can reduce the status of the critic. According to Klein, this is due to the lack of formal training characteristics from critics; besides that, the qualifications of famous music critics are very weak because cultural authority is not consistently built [6]. Klein's view provides input on this research, how music criticism must have cultural muscles that meet high qualifications, such as maturity of knowledge, broad insight and have competent cultural authority in the eyes of the wider community.

This study looks different from the research above; this can be seen from the proposed subject. We know that music has a variety of different genres, but the uniqueness can be seen from each of these genres. There is pop or commonly called popular music, punk, heavy metal, hip-hop, Malay dangdut, and some are now called folk music. Folk has the meaning of the words citizen or similar meanings of people as a whole. Folk music has the same meaning as world music or ethnic music [7]. If it is seen from the meaning of the word folk, presumably, we can guess if the concoction of music must be attached to simplicity and everyday life. Folk songs do not traditionally have commercial ownership, even though the songs are made for popular listeners. They often end up being included in a folk concept for generations; we can also differentiate traditional music players from their family origins [8]. Folk music includes some of the following characteristics: (1) the origin of the location in a particular culture or religion; (2) authorships that are historically unknown, through the writers who appeared two centuries earlier; (3) traditionally performed by people who are not professional, can be acoustic musical instruments; (4) natural composition, with a small likelihood of difficulty so that it can be demonstrated and distributed together; and (5) songs that have historically been handed down through oral transmission [9].

The development of folk music in Indonesia itself shows excellent progress, from musical instruments involving traditional musical instruments to the enthusiasm of the fans. Namely, the Indonesian folk music frontman Gordon Tobing, Franky Sahilatua, Iwan Fals (the 80s-90s era), Ebiet G. Ade, Gipsy Guruh to Vicky Sianipar, and Discus. From the several musicians mentioned, Iwan Fals is one of the folk musicians who, in his songs, takes many social themes that describe a criticism, besides, examples of other musicians outside the folk genre whose music illustrates criticism and social themes are Efek Rumah Kaca and Navicula. For some musicians, music is considered as the right media as a messenger. Their songs, whose lyrics written are criticism of humans or even the government, such as the song of Iwan Fals criticized the government during the New Order era. Navicula conveys environmental issues that are contaminated and endangered rare animals. Efek Rumah Kaca also addresses political and social issues in their songs. Every song that is made has other elements besides as an entertainer.

Moreover, with music, they can anesthetize fans to voice messages on these songs. In addition to the great musicians mentioned earlier, Yogyakarta has one of the musicians whose songs have a folk nuance containing social criticism towards the public, namely Sisir Tanah. Sisir Tanah is a music project originating from Bantul, Special Region of Yogyakarta, established in 2010. Sisir Tanah was created to accommodate works by Bagus Dwi Danto. Some songs talk about personal, and others contain social criticism. 


\section{Method}

The researcher is interested in raising social criticism towards Sisir Tanah music, which is seen from the listener's perspective, a song which is the media, and Sisir Tanah is a communicator. For example, the simple process of delivering one's thoughts or feelings to others by using the symbol as a medium, the symbol is in the form of music and lyrics on the Sisir Tanah. The researcher wants to discuss the lyric message poured by Sisir Tanah on music that contains social criticism and sees the contents of the message in the eyes of the audience, that whether the audience can thoroughly receive the contents of the message from songs to the audience. Thus it will be seen how active listeners perceive songs of social criticism in Sisir Tanah songs. Different viewpoints from the listeners will be seen on how the influence of the message conveyed by the Sisir Tanah. From all the songs available, the researcher will take two songs, Hidup means life, and Bebal means ignorant. In both songs, there is social criticism about the environment. Interestingly, not many people know about Sisir Tanah, a musician who was born and raised in Yogyakarta, especially his songs are mostly idealistic about criticism, and one of them is the environment.

This type of research is qualitative description research with a reception analysis method. The descriptive method is a method used to look for the elements, characteristics, characteristics of a phenomenon. This method starts by collecting data and interpreting it [10]. Reception analysis is a particular part of the audience study that tries to examine in depth. The reception has three main elements called "The Collection, Analysis, and Interpretation of Reception Data." First is collecting data from the audience or interviewing participants to explore a particular media message. Second, analyzing the results or theme of the interview or the recording of the process of the Focus Group Discussions (FGD). Review the interview notes, which are then summarized into various categories. Moreover, the third is interpreting media experiences from the audience [11]. The audience will perceive the object chosen by the researcher, an interview with audiences is conducted, and the results are analyzed.

In the data collection technique, a semi-structured interview is used to obtain influence and interpretation from informants on Sisir Tanah songs. Here, the researcher will interview naturally so that the informant is more open to the researcher, making it easier for the researcher to be able to find out the opinion of the informant. In this structured interview, interviewers usually have a list of written questions, but it is possible to ask questions about the problem freely. However, directed by staying on the main point of the problem that will be asked and prepared beforehand [12]. In this qualitative study, the sample used is purposive. The purpose of this sample is to obtain information from the informants, and each informant will be interviewed or sample determination techniques for specific purposes [13]. Such as the criteria of the interviewed audience is the audience who listens to a variety of music genres, actors in the Indie music industry, and music audiences who listen to only one music. From the criteria stated earlier, the informant is included in the audience of music that is indeed daily listening and concern for music.

\section{Results and Discussion}

This research understands that useful social criticism must come from and relate to the customs and traditions of people who actually lived in a particular time and place [14]. Social criticism is, at the same time, a form of communication in a society that aims or functions as control over the running of a social system or social process. Social criticism is an essential variable in maintaining social systems. Various actions that deviate from social and moral values in society can be prevented by social criticism. In other words, the function of social criticism is as a means of preserving and reproducing a social system or society. The song that will get attention in this analysis is entitled Sisir Tanah, a song titled Hidup, and Bebal. This song was discussed quite a lot by the audience because it contained social criticism. The lyrics for the song titled Hidup are shown in Table 1, and the lyrics for the song entitled Bebal are shown in Table 2.

These two songs are enough to be discussed by the audience in perceiving songs that contain social criticism, so it is enough to feel whether music as a medium for delivering messages can represent Sisir Tanah songs well. From this reception analysis, the audiences who get the message will perceive the two of Sisir Tanah songs, so that the impact of the message will be seen through the listeners. 
Table 1. The song lyrics of Sisir Tanah studied is a song titled Hidup

\begin{tabular}{cc}
\hline Sisir Tanah song titled Hidup & Meaning \\
\hline Kita akan selalu butuh tanah & We will always need land \\
Kita akan selalu butuh air & We will always need water \\
Kita akan selalu butuh udara & We will always need air \\
Jadi teruslah merawat & So keep caring \\
Jika kau masih cinta kawan dan saudara & \\
Jika kau masih cinta kampung halamanmu & If you still love friends and relatives \\
Jika kau cinta jiwa raga yang merdeka & If you still love your hometown \\
Tetap saling melindungi & If you love a free body and soul \\
Kan harus berani, harus berani & Keep protecting each other \\
Jika orang-orang serakah datang & \\
Harus dihadang & And must be brave, must be brave \\
Harus berani, harus berani & If greedy people come \\
Jika orang-orang itu menyakiti & Must be intercepted \\
Harus bersatu menghadapi & Must be brave, have to be brave \\
manusia & If people are hurting \\
Bahagiaku takkan lengkap tanpa bahagiamu & Must unite to facing \\
Bahagiakanlah kehidupan & Your sadness is my sad too \\
Dan harus berani, harus berani & Your pain my pain we humans pain \\
Harus berani, harus berani, harus berani & My happiness won't be complete without your happiness \\
Harus berani, harus berani, harus berani & Make life happy \\
& And must be brave, must be brave \\
& Must be brave, must be brave, must be brave
\end{tabular}

Table 2. The song lyrics of Sisir Tanah studied is a song titled Bebal

\begin{tabular}{|c|c|}
\hline Sisir Tanah song titled Hidup & Meaning \\
\hline $\begin{array}{l}\text { Jika bumi adalah ibu. } \\
\text { Kita manusia memperkosa ibunya. } \\
\text { Setiap hari. Setiap jam. Setiap menit. Setiap detik. } \\
\text { Jika laut adalah ibu. } \\
\text { Kita manusia memperkosa ibunya. }\end{array}$ & $\begin{array}{l}\text { If the earth is the mother. } \\
\text { We, humans, raped their mothers. } \\
\text { Every day. Every hour. Every minute. Every second. } \\
\text { If the sea is the mother. } \\
\text { We, humans, raped their mothers. }\end{array}$ \\
\hline $\begin{array}{l}\text { Setiap hari. Setiap jam. Setiap menit. Setiap detik. } \\
\text { Jika hutan adalah ibu. } \\
\text { Kita manusia memperkosa ibunya. } \\
\text { Setiap hari. Setiap jam. Setiap menit. Setiap detik. Ada, } \\
\text { tak ada manusia mestinya }\end{array}$ & $\begin{array}{l}\text { Every day. Every hour. Every minute. Every second. } \\
\text { If the forest is the mother. } \\
\text { We, humans, raped their mothers. } \\
\text { Every day. Every hour. Every minute. Every second. } \\
\text { There are, no humans should }\end{array}$ \\
\hline $\begin{array}{c}\text { Pohon-pohon itu tetap tumbuh. } \\
\text { Ada, tak ada manusia mestinya Terumbu karang itu } \\
\text { tetap utuh. } \\
\text { Ada, tak ada manusia mestinya } \\
\text { Pohon-pohon itu tetap tumbuh. } \\
\text { Ada, tak ada manusia mestinya Terumbu karang itu tetap } \\
\text { utuh. }\end{array}$ & $\begin{array}{l}\text { The trees keep growing. } \\
\text { There is no human being should the coral reefs remain } \\
\text { intact. } \\
\text { There is no human being. } \\
\text { The trees should still grow. } \\
\text { There is no human being should the coral reefs remain } \\
\text { intact. }\end{array}$ \\
\hline
\end{tabular}

The underlying meaning of the word Sisir Tanah is agricultural tools commonly used to cultivate the land, or another word is a rake that functions to destroy chunks and loosen up the soil. So Sisir Tanah is the Indonesian equivalent of rakes. Sisir Tanah was formed in 2010, initially started as a musical project of poetry by Bagus Dwi Danto, whose work was written long before Sisir Tanah was formed. Danto, a man, born in 1978 who is now 40 years old, has been playing music for almost eight years. At first, Sisir Tanah simply recorded the songs and then shared them in the music application, Soundcloud. It was recorded more seriously and was packaged on the debut album; it was finally released in early May 2017 entitled "WOH," produced by the Laras Music Study Foundation. "WOH" in Javanese means "fruit" as a symbol for the work of Sisir Tanah, who has been in the process for seven years in the music field. The launching of the Sisir Tanah album took place at IFI Yogyakarta. Sisir Tanah also had a tour in several cities on the island of Java and East Kalimantan Province to introduce his work. The tour, titled "Must Be Brave Tour 2017," was held from mid-April to early May 2017 before holding the launch of the album. 
Danto writes about socialist realism - criticizing the environment, talking about the world through the public's eyes, not the bourgeoisie. No wonder that Danto's background is also a humanitarian activist who is affiliated with a collective of socialist realism-art that is indeed concerned with significant issues. The brightest part of the musical project from Sisir Tanah that strengthens the songs in Danto's music is the lyrics that contain meaning or text made with writing, which is quite typical for Sisir Tanah. The text is a pleasure in which the lyrics are literary works used as music, as described previously (the musical project of poetry). The pleasure of a text is the pleasure when browsing each page after page of the object being read. Likewise, the lyrics have their feelings that cannot be shared by others because enjoyment is built according to the imagination of the listeners [15]. Support is born from enthusiasm. That spirit must be started and fostered by oneself.

Sisir Tanah songs want to convey about humans and the problems that accompany them-starting from social, cultural, and nature. In making the song lyrics, the purpose of the song must be understood, hoping that the songs bring good messages or the fundamental social criticism of life. The criticism itself is usually focused on the current social or political situation. Music that has an element of criticism has the potential to support educational activities. When music can educate the public, music can also move the people just to join or support the movement. The mobilization of the people provides an opportunity for many audiences to voice their ideas without fear. Music containing criticism or protest is inseparable from popular culture [16].

The reason why Sisir Tanah takes a social theme in its songs is that the theme is intended for everyone, so it needs to be conveyed continuously. According to Danto, he takes music as a medium because Sisir Tanah is in music; the song is a way to convey his messages. It was starting with a small scope in order to become a beginning that will continue to be disseminated wherever Danto plays. When asked about the intentional elements in his songs, Danto said, "all songs are generally deliberately made as songs, there is nothing becomes a song by itself. Regardless of the purpose of making a song". Danto means the song is made intentionally with or without the purpose of making the song exist and being sung; it will be related to the purpose of why Sisir Tanah is made, the theme raised, and also the realm. Using music as social criticism is a distinct and a great idea to get a message across to the crowd. This study understands that a song is the work of a musician that is made not only for entertainment but also for the listeners to enjoy or even work for personal enjoyment, which ultimately is very popular with the public. This is very natural in music; some musicians sometimes consider how famous they are even though there are not many works. Popularity makes musicians forget what they should be aiming for.

Generally, music audiences will listen to music from various media, and audiences can be said as judges for musicians. The public will comment a lot on the songs they do not like; on the other side, the audience will praise if the song can get into the audience. This is audience support for musicians. Moreover, it is not surprising that the audience is choosy in the matter of the song being listened to, because it is related to taste. Musicians or others cannot force anyone to like a song that is not necessarily liked. The music itself has various types and elements in its contents, as it is known that there are some music or songs that do raise themes about social criticism. The content of music is included in social elements which aim to make the listener can hear and feel what is conveyed from the musician. Usually, musicians with works leading to social criticism do not care how great the songs are created, but rather how broad the public can listen and be appreciated. Sisir Tanah is a musician whose works contain social criticism. Social criticism that is discussed nowadays is a social problem on the environment in which environmental issues have several categories, namely, a physical environment that is all inanimate objects that are around humans. A biological environment is everything around humans in the form of living organisms. The social environment consists of people, both individuals, and groups, around humans [17]. The environment, which includes matters caused by interactions between living organisms, consists of humans, animals, and plants, which collectively influence and are influenced by the environment. Humans are the most dominant element in the background. Humans can change quantitatively, with their intelligence, humans are also able to improve themselves qualitatively. Because humans are the dominant factor, the target is also focused on the mutual influence between humans and the environment in various aspects (ecosystem) [18].

Social criticism in Sisir Tanah songs is a critique of the problem about the biological environment, in which something that surrounds humans is a living organism. A biological environment means a collection of mutual influence so that it functions stably and has a living nature. That is why Sisir Tanah, in this song, is quite concerned about land, sea, forest. Because everyone in the community 
has the right to grow and live, especially living organisms, it is an essential need for society itself. The natural environment has a life that is usually ruled out by society. Sisir Tanah has two song titles that attract the public, namely Hidup and Bebal. Both songs, when uploaded to the Soundcloud account, were listened to by the public, and on average, they gave positive reactions. Why? Because the two songs contain socio-environmental problems that occur in Yogyakarta. Some time ago, in the Yogyakarta, precisely in the Kulon Progo region, a conflict occurred where the land of fishers and farmers were evicted for the benefit of the state, that is why this is the right time for Sisir Tanah to raise these social issues. The songs get the right time to continue spreading the message. For Sisir Tanah, making themed songs that touch humanitarian issues will automatically bring them closer to reality - feeling inseparable and beneficial as a human being. It can be closer to reality, including sensitivity. This can sharpen sensitivity over time. The making of songs only trusts intuition. Indeed it continues to hone him to make the song deeper like the existing issues.

Talking about social criticism, according to Labib, is a message to correct the relationship between humans and other humans. If something is not right yet, it is necessary to express the opinion that it should be. According to Labib, social criticism using songs is the art of communicating using music to respond to behavior mismatches in society. Social criticism of using music is an opinion, a suggestion from the author, which is conveyed in a song. From so many Sisir Tanah songs, Labib listens to two songs at the interview. In his perspective in Hidup, he says, "Hidup song tells about togetherness to do courage, togetherness in friendship. If there is something that he thinks is not acceptable enough, if we need to fight, we fight". The reception captured by Labib on Hidup song is like a struggle fellow friends who have a purpose; if fighting is a good thing, then fighting with friends is a goal that should be. Whereas in the second song entitled Bebal, he says, "We are too arbitrary with nature, exploiting nature. The presence or absence of humans, nature can live. The existence of humans, nature is no longer beautiful because humans are so arrogant". Humans indeed have the highest degree among living things, animals, and plants. That way, humans become arbitrary from what has been given. According to Labib, when humans have colonized nature, it will be damaged by exploitation.

In a discussion with Riska about social criticism, she says that social criticism is like telling a listener that the current state of the environment or surroundings is not okay. Indeed, what causes it is human activity. That way, criticism of songs can be useful because the choice of words used can still be understood and directly to its true intentions, not using words that make the listener have to think first the intentions of the songwriter. Besides, simplicity makes the listener more severe and focused because, inevitably, the song lyrics that sound clear, and the strength of the song do exist in the lyrics. In her opinion, Sisir Tanah has sad music. She says that Sisir Tanah talks more about its surroundings, about the nature that Sisir Tanah highlights. What is felt, what is observed in the environment? By bringing an acoustic solo or inviting a friend. Simple but attractive to listeners. For Riska, Sisir Tanah's work cannot be separated from criticism of environmental issues. Through the song, Sisir Tanah gives a proper response and narrates the message intones. Through songs, listeners get messages and get warnings to pay attention to the natural environment. That is why these songs can be categorized as social criticism. Riska adds that the lyrics which go straight to the core of the problem are easier to understand, how to convey the message in the lyrics as the listener interprets the lyrics. However, sometimes to support his performance, he collaborates several times with performing art to visualize the meaning of the song; maybe criticism of songs can be made that way so that the intentions of songs containing criticism can be conveyed more. In understanding Sisir Tanah's songs, Hidup, Riska interprets that this song criticizes the social, tells, and complains to the public about the state of nature, monopolized. Indeed, Sisir Tanah tells more about natural conditions, the environment around the community, and the people who do not take care of the environment properly.

While, Bebal song captured by Riska, is "as stated in the title, that Bebal means ignorant or hard to tell." Because Sisir Tanah talks a lot about the natural environment, about what is felt around it. Danto criticized people for opening their eyes and seeing the conditions that people do. She thinks that the song refers to people who are hard to tell. When he first listens to the song Sisir Tanah, Mr. Dedy has the thought that the social criticism conveyed can still be said to be ordinary; his expression is also modeled on irony and cynicism. According to him, the social criticism of Sisir Tanah is not as hard as WS Rendra's portrait of development in poetry. Musicals of poetry with songs are two things in stock. However, the tendency of musicals of poetry is a limited sound (the song is limited) like people reading poetry accompanied by music. However, Ebiet G. Ade can take musical poetry with a 
professional, and his voice is right. In his views, actors and consumers must be reminded of each other; the songs are more likely to be environmental preservation. The songs of "Sisir Tanah" in the art are naturalist social critics. They often talk about their badness, which aims to remind them about the environment damaged and not protecting the environment. In his opinion, Sisir Tanah tends to take on natural themes such as exploiting nature and forests. The problem in social criticism being raised to the song made him think, "is it so bad?" Such severe forests and coral reefs have been exploited for subsistence needs. "Who is that exploitation for?"

In interpreting the song Sisir Tanah, according to him, the parable in Bebal is the personification of the forest as the mother; if humans injure the forest, it is the same as hurting the mother. It is not rude or harsh, just a reminder. Is it right? Because Indonesia is called the motherland. So the forest, land, water, sea, air are mothers because they are called motherland. In the fragment of the song's lyrics, "raping mother" is a familiar parable and not challenging. As a music audience, Mr. Dedy feels that the song cannot be felt by just listening once, arguing that the words in the lyrics are not strong enough with only four stanzas, then the parable is still said to be ordinary. Compared to the poems written by WS Rendra or Ebiet G Ade, Sonnia in interpreting Hidup is a work to make people aware of loving their homeland, loving the earth always to be cared for because many people forget to take care of what they have. In this song, Sonnia can quickly understand the purpose of the song, maybe because there is no parable and particular purpose in the lyrics. Danto, in the lyrics of the song, has conveyed clearly. As in the section of the lyrics, "still protect each other," which means humans and nature protect and care for each other. Whereas Bebal, from her point of view, "this song, Bebal is challenging to understand because Sisir Tanah uses a language that only musicians understand themselves. Too literary so that it has its meaning.

Moreover, Bebal still tells about nature that must be cared for and guarded. Sonnia cannot quickly respond to lyrics that use parables; not all the lyrics read can be appropriately absorbed. Occasionally Sonnia is still confused by the parable of the lyrics. Sometimes what is thought is not the same as the original meaning because it is not directly translated (there is a meaning behind the lyrics). From Fachri's perspective, the message about the environment is what he catches after hearing Sisir Tanah songs. About what is happening to our earth today, with the exploitation everywhere. Sisir Tanah is relatively straightforward in voicing the rights of our earth by pronouncing the words "opponent" in the lyrics for people who treat the earth improperly. Responding to social criticism in music, Fachri believes that Bebal and Hidup songs are right if called as part of social criticism. Because the song is a satire for people who damage the environment, according to Fachri, social criticism conveyed through Sisir Tanah songs cannot be directly digested by the laity. Because to digest the lyrics, people have to listen to it many times and need enough thought. When compared with previous social criticism songs such as Iwan Fals and Ebiet G. Ade, according to Fachri, the song Sisir Tanah is challenging to understand. This is seen in the style of speech and tone conveyed by Danto. When asked about the effectiveness of social criticism in songs, Fachri answers, "social criticism in music will be right for people who love music, because people like that not only listen briefly but also understand." At the reception, Fachri says that Hidup can be crowned as an anthem of resistance for them, damaging the environment.

The exclamation in the lyrics "if greedy people come, must be intercepted, must be brave, must be brave," and in the Bebal song, Fahri argues that Sisir Tanah tells how unconsciously we as humans have damaged our earth. From the sea, the air to the land, there have been many exploits by humans. Sisir Tanah tries to highlight that by likening the act of rape. According to Fachri, the lyrics are quite intelligent by comparing the earth as a mother, and exploitation act as an act of rape. In this study, the listeners who become informants receptive to what social criticism in Sisir Tanah songs, such as responses to social criticism in Sisir Tanah songs, the results of the representation of the five informants as follows;

- The social criticism of the song Sisir Tanah, which is featured in the two songs entitled Hidup dan Bebal, tells about social and natural environmental problems caused by human activity.

- Art in the form of a pitched voice (song) contains the message of a songwriter's response to the incompatibility of existing behavior in the community. The point is that social criticism is an opinion, a suggestion from the author delivered in the form of a song. 
- Sisir Tanah songs tend to preserve the environment where art is a naturalist social critic that talks a lot about its badness, which aims to remind about the environment damaged, not protecting the natural environment.

- This social criticism is aimed more at people who have forgotten nature, the earth that already exists in the world. To make people more aware, not less care.

- Social criticism can be a satire for people who damage the environment that in the songs of Sisir Tanah may not be understood just by once or twice listening, and these songs are social problems to the environment that occur on earth today, with the exploitation everywhere.

The reception made by the five informants was quite active in processing the criticism messages, so that Labib, Riska, Mr. Dedy, Sonnia, and Fachri produce a message from the media and then interpret it in their perspectives. Thus the data obtained from the five informants are presented again with the addition of opinions, assessments, and experience. The points mentioned are the results that have been represented in each informant. Social criticism exists because of social problems in the community, which have been discussed that the problem of social criticism in Sisir Tanah songs is the environment and nature. With that, Sisir Tanah is there to remind humans, Sisir Tanah can be likened to an alarm for the public or listener. With the social movements that are built by someone, music can become a sweetener and the medium. Critics of environmental problems want to be addressed to what has been done so that there is no sense of concern in this society, with music, it can be another way for someone to show or express.

Moreover, the media currently has too many camps created, and this can go to the stronghold. For this purpose, music listeners can find out environmental issues and take part in caring. The phenomenon of a critical song written by Sisir Tanah is a general description of social and environmental problems that occur in Indonesia. Sisir Tanah will continue to take this step as a response to the mismatched social and environmental conditions. With the song of Sisir Tanah, at least the message is delivered even though some listeners are not the same in perceiving messages from Sisir Tanah. Social problems such as the environment to nature will never end to be discussed, especially the approach that should be conveyed to music listeners and more than that. The criticism of Sisir Tanah songs felt by the five informants is an environment that is damaged and even exploited by humans. This environment is increasingly a crisis or global warming; the allusions delivered so that the message of criticism continues to hit the listener. The point of the five informants, social criticism on the songs of Sisir Tanah, is exploitation, genetic damage caused by humans themselves, satire, lack of human concern. These points can be the basic things that people can instill from what is delivered in the song. For once or twice listening, the effects of the critics have not been to a severe stage. There is no coercion from Danto; everything can be felt by the audience because, in the analysis of the reception, the media text is not attached to the text; on the contrary, it is created in the interaction between the audience and the text. It can be said that a Sisir Tanah song will make a reaction to the listener if the listener interacts with the song, where the song that is perceived to the five informants becomes a point.

\section{Conclusion}

Both songs are musical poetry by Danto, which contains criticism on social and environmental themes. The message is to protect the natural environment so that humans can coexist. The two songs Sisir Tanah are a protest to the people who have destroyed nature and the environment. Through the media of music, Sisir Tanah uses his songs as a form of protest. Listeners or the public must care about music as a medium for conveying messages containing social issues to become a reminder to protect the environment and nature. Many things can be achieved from a musical work that voices social issues that highlight the environment where music can be a medium of mass communication among other media. Hopefully, this research can add references, or this research can be continued to further researchers.

\section{References}

[1] F. Setyaningrum, H. Siswantari, L. L. Simatupang, and P. D. Fitriasari, "Hidden Curriculum Design of Traditional Art Community Rampak Kendang," Int. J. Vis. Perform. Arts, vol. 1, no. 2, pp. 90-97, Dec. 2019, doi: 10.31763/viperarts.v1i2.65. 
[2] J. Anderson and A. D. Kincaid, "Media Subservience and Satirical Subversiveness: The Daily Show , The Colbert Report, The Propaganda Model and the Paradox of Parody," Crit. Stud. Media Commun., vol. 30, no. 3, pp. 171-188, Aug. 2013, doi: 10.1080/15295036.2013.771276.

[3] C. Hoedemaekers, "Creative work and affect: Social, political and fantasmatic dynamics in the labour of musicians," Hum. Relations, vol. 71, no. 10, pp. 1348-1370, Oct. 2018, doi: 10.1177/0018726717741355.

[4] S. McClary, “Towards a Feminist Criticism of Music," Can. Univ. Music Rev., vol. 10, no. 2, p. 9, 1990, doi: 10.7202/1014882ar.

[5] R. Weitzman, “An Introduction to Adorno’s Music and Social Criticism,” Music Lett., vol. LII, no. 3, pp. 287-298, 1971, doi: 10.1093/ml/LII.3.287.

[6] B. Klein, "Dancing About Architecture: Popular Music Criticism and the Negotiation of Authority," Pop. Commun., vol. 3, no. 1, pp. 1-20, Feb. 2005, doi: 10.1207/s15405710pc0301_1.

[7] J. Haynes, "World music and the search for difference," Ethnicities, vol. 5, no. 3, pp. 365-385, Sep. 2005, doi: $10.1177 / 1468796805054961$.

[8] Rees, "Environmental Crisis, Culture Loss, and a New Musical Aesthetic: China's 'Original Ecology Folksongs' In Theory and Practice," Ethnomusicology, vol. 60, no. 1, p. 53, 2016, doi: 10.5406/ethnomusicology.60.1.0053.

[9] A. Cohen and S. L. Rosenhaus, "Folk music: the basics," in Writing Musical Theater, New York: Palgrave Macmillan US, 2006, pp. 3-13. https://doi.org/10.1007/978-1-137-04810-3

[10]H. Nassaji, “Qualitative and descriptive research: Data type versus data analysis," Lang. Teach. Res., vol. 19, no. 2, pp. 129-132, Mar. 2015, doi: 10.1177/1362168815572747.

[11]B. MacGregor and D. E. Morrison, "From focus groups to editing groups: a new method of reception analysis," Media, Cult. Soc., vol. 17, no. 1, pp. 141-150, Jan. 1995, doi: 10.1177/016344395017001009.

[12] S. Q. Qu and J. Dumay, “The qualitative research interview," Qual. Res. Account. Manag., vol. 8, no. 3, pp. 238-264, Aug. 2011, doi: 10.1108/11766091111162070.

[13] I. Etikan, "Comparison of Convenience Sampling and Purposive Sampling," Am. J. Theor. Appl. Stat., vol. 5, no. 1, p. 1, 2016, doi: 10.11648/j.ajtas.20160501.11.

[14]D. A. Bell, "Communitarianism," in Wiley Encyclopedia of Management, Chichester, UK: John Wiley \& Sons, Ltd, 2015, pp. 1-3. https://doi.org/10.1002/9781118785317.weom020091

[15] V. Tohar, M. Asaf, A. Kainan, and R. Shahar, "An Alternative Approach for Personal Narrative Interpretation: The Semiotics of Roland Barthes," Int. J. Qual. Methods, vol. 6, no. 3, pp. 57-70, Sep. 2007, doi: 10.1177/160940690700600306.

[16]P. Franklin, "Audiences, Critics and the Depurification of Music: Reflections on a 1920s Controversy," J. R. Music. Assoc., vol. 114, no. 1, pp. 80-91, Jan. 1989, doi: 10.1093/jrma/114.1.80.

[17] L. C. Li, J. M. Grimshaw, C. Nielsen, M. Judd, P. C. Coyte, and I. D. Graham, "Evolution of Wenger's concept of community of practice," Implement. Sci., vol. 4, no. 1, p. 11, Dec. 2009, doi: 10.1186/17485908-4-11.

[18] J. Graff Zivin and M. Neidell, "Environment, Health, and Human Capital,” J. Econ. Lit., vol. 51, no. 3, pp. 689-730, Sep. 2013, doi: 10.1257/jel.51.3.689. 